\title{
Relationships among Soluble Phenolics, Insoluble Proan- thocyanidins and Fiber in East African Browse Species
}

JESS D. REED

\begin{abstract}
Tannins and other phenolics interfere with the interpretation of results from the detergent system of forage analysis. Leaves and apices from browse can contain up to $50 \%$ of their organic matter as phenolics including tannins that are soluble in aqueous acetone. Leaves and apices from browse that contain soluble proanthocyanidins (condensed tannins) also contain proanthocyanidins that are insoluble in both aqueous acetone and neutral-detergent. The content of insoluble proanthocyanidins is positively correlated with neutral-detergent fiber (NDF) and fiber-bound nitrogen. Condensed tannins may bind protein and make it less soluble in neutral-detergent and increase the content of NDF. The behavior of phenolics and tannins in the detergent system of forage analysis is discussed in relationship to estimating the nutritive value of 17 East African browse species.
\end{abstract}

The detergent system of forage fiber analysis and the partitioning of cell wall from cell contents is widely used in determining the nutritive value of browse in the diets of mammalian herbivores (Van Soest 1967, 1982; Mould and Robbins 1981). Soluble phenolics and tannins can lower nutritive value of forages by toxic effects on the animal or through enzyme inhibition and substrate binding in the digestive tract (Wong 1973, Swain 1979). Insoluble proanthocyanidins (condensed tannins) occur in the leaves of legumes and other plant species (Bate-Smith 1973, 1975), but their effects on nutritive values have not been sufficiently studied. Insoluble proanthocyanidins may be involved in plant defense, associated with insoluble and enzyme resistant protein, and negatively associated with digestibility and palatability (Ford 1978, Stafford and Cheng 1980, Reed et al. 1982). An understanding of the relationship of tannins and other phenolics to the detergent system is essential to its use in predicting nutritive value of browse (Mould and Robbins 1981).

\section{Materials and Methods}

Browse samples were collected over a 9-month period, including 1 dry season and 2 wet seasons, in Kenya during a study on the nutritional ecology of game and cattle (Reed 1983). Leaves and apices from 17 species, 39 samples (Table 1), were air dried in a well-ventilated room. Due to low humidity drying occurred in 24 to 48 hours. The species sampled are important in the diets of wild and domestic ungulates.

Neutral-detergent fiber (NDF), acid-detergent fiber (ADF), acid-detergent lignin, hemicellulose, and cellulose were determined by the methods of Goering and Van Soest (1970), omitting decahydronaphthalene and sodium sulfite in the NDF procedure (Van Soest and Robertson 1980). Proanthocyanidins insoluble in neutral detergent were determined by methods described by BateSmith (1973) as modified by Reed et al. (1982). Five milligrams of NDF were placed in a test tube, $5 \mathrm{ml}$ of $5 \%$ concentrated $\mathrm{HCl}$ in a n-butanol were added and the tubes heated at $100^{\circ} \mathrm{C}$ for 1 hour. Absorbance was read at $550 \mathrm{~nm}$. If proanthocyanidins were present in the NDF, the n-butanol- $\mathrm{HCl}$ solution turned red when heated. Results were expressed as $A_{550}$ per gram of NDF. Nitrogen in the NDF (NDF-N) of Acacia species was determined by a macro-Kjeldahl procedure using $\mathrm{Na}_{2} \mathrm{SO}_{4}$ and $\mathrm{CuSO}_{4}$ in the diges-

Author is animal nutritionist, International Livestock Centre for Africa, Addis Ababa, Ethiopia, P.O. Box 5689

Manuscript accepted 9 May 1985
Table 1. Neutral-detergent fiber (NDF), soluble phenolics and insoluble proanthocyanidins in East African browse.

\begin{tabular}{|c|c|c|c|c|}
\hline Species & Part & $\begin{array}{c}\text { NDF } \\
(\% \mathrm{OM})\end{array}$ & $\begin{array}{c}\text { Soluble } \\
\text { Phenolics } \\
\text { (\%OM) }\end{array}$ & $\begin{array}{c}\text { Insoluble } \\
\text { Proantho- } \\
\text { cyanidins } \\
\text { (A560/g NDF) }\end{array}$ \\
\hline Acacia albida & Leaves & 39.9 & 21.5 & 17.3 \\
\hline Acacia brevispica & Leaves & 42.7 & 18.4 & 16.9 \\
\hline Acacia drepanolobium & Leaves & 42.5 & 24.8 & 31.5 \\
\hline Acacia drepanolobium & Leaves & 47.3 & 18.7 & 47.5 \\
\hline Acacia drepanolobium & Apices & 44.5 & 22.7 & 58.9 \\
\hline Acacia drepanolobium & Leaves & 45.2 & 24.5 & 88.8 \\
\hline Acacia drepanolobium & Apcies & 44.9 & 14.5 & 36.4 \\
\hline Acacia etbaica & Leaves & 39.2 & 33.6 & 6.5 \\
\hline Acacia mellifera & Leaves & 42.5 & 23.8 & 5.6 \\
\hline Acacia mellifera & Leaves & 37.1 & 22.4 & 5.7 \\
\hline Acacia mellifera & Leaves & 34.1 & 24.1 & 31.8 \\
\hline Acacia mellifera & Apices & 37.0 & 18.0 & 32.8 \\
\hline Acacia nilotica & Leaves & 20.1 & 59.4 & 2.6 \\
\hline Acacia nilotica & Leaves & 23.7 & 56.1 & 2.7 \\
\hline Acacia nilotica & Apices & 23.6 & 59.8 & 2.0 \\
\hline Acacia senegal & Leaves & 41.2 & 15.4 & 4.1 \\
\hline Acacia seyal & Leaves & 22.4 & 41.0 & 2.0 \\
\hline Acacia seyal & Apices & 20.7 & 54.5 & 1.6 \\
\hline Acacia seyal & Leaves & 20.4 & 46.5 & 2.9 \\
\hline Acacia seyal & Apices & 18.7 & 51.9 & 3.7 \\
\hline Acacia xanthophloea & Leaves & 39.2 & 25.6 & 47.2 \\
\hline Acacia xanthophloea & Leaves & 43.4 & 25.1 & 106.8 \\
\hline Acacia xanthophloea & Apcies & 45.1 & 31.0 & 57.8 \\
\hline Albizia harveyii & Leaves & 64.4 & 14.4 & 420.5 \\
\hline Albizia harveyii & Leaves & 58.8 & 22.5 & 370.0 \\
\hline Albizia harveyii & Apices & 40.8 & 18.4 & 104.5 \\
\hline Carissa edulis & Leaves & 38.1 & 30.6 & 153.3 \\
\hline Carissa edulis & Leaves & 42.1 & 29.6 & 185.2 \\
\hline Carissa edulis & Apices & 41.7 & 25.7 & 302.4 \\
\hline Commifera schimperi & Leaves & 36.5 & 18.0 & 225.0 \\
\hline Grewia tembensis & Apices & 43.5 & 17.3 & 37.8 \\
\hline Grewia tembensis & Apices & 40.9 & 14.7 & 27.7 \\
\hline \multicolumn{5}{|l|}{ Ormocarpum } \\
\hline trachycarpum & Leaves & 37.0 & 19.6 & 109.6 \\
\hline \multicolumn{5}{|l|}{ Ormocarpum } \\
\hline trachycarpum & Apices & 33.8 & 23.5 & 93.4 \\
\hline Phylanthus sepialis & Leaves & 34.6 & 14.7 & 9.8 \\
\hline Phylanthus sepialis & Apices & 27.5 & 16.3 & 23.4 \\
\hline Pterolobium stellatum & Leaves & 23.4 & 43.4 & 16.0 \\
\hline Rhus natalensis & Leaves & 66.1 & 15.0 & 410.0 \\
\hline Rhus natalensis & Apices & 64.9 & 13.0 & 435.5 \\
\hline mean & & 38.7 & 27.4 & 90.6 \\
\hline standard deviation & & 11.9 & 13.7 & 127.8 \\
\hline
\end{tabular}

tion mix and collecting the distillate in a boric acid solution. NDF-N was determined only in the Acacia species because these samples contained similar levels of total N. Phenolics and tannins soluble in aqueous acetone were determined by a gravimetric procedure based on precipitation by ytterbium acetate (Reed et al. 1985). All determinations were conducted in duplicate.

\section{Results}

Variation in the NDF, soluble phenolics, and insoluble proanthocyanidins was large (Table 1). There were only small differences 
Table 2. Correlations between neutral-detergent fiber (NDF), acid-detergent fiber (ADF), hemicellulose (HEM), cellulose (CELL), lignin (LIG), soluble phenolics and insoluble proanthocyanidins (A550/g NDF) in leaves and apices of 17 East African browse species (39 samples).

\begin{tabular}{lccccc}
\hline \hline & Soluble phenolics & $\begin{array}{c}\text { Insoluble } \\
\text { proanthocyanidins }\end{array}$ & NDF & ADF & HEM \\
\hline A550/NDF & $-0.39^{* *}$ & & & & \\
NDF & $-0.72^{* * *}$ & $0.75^{* * *}$ & & & \\
ADF & $-0.62^{* * *}$ & $0.75^{* * *}$ & $0.88^{* * *}$ & & \\
HEM & $-0.58^{* * *}$ & $0.47^{* * *}$ & $0.79^{* * *}$ & $0.39^{* *}$ & \\
CELL & $-0.66^{* * *}$ & $0.55^{* * *}$ & $0.68^{* * *}$ & $0.81^{* * *}$ & 0.26 \\
LIG & $-0.40^{* *}$ & $0.70^{* * *}$ & $0.79^{* *}$ & $0.88^{* * *}$ & $0.37^{* *}$ \\
\hline
\end{tabular}

$* * p<0.01$
$* * * * 0<0.001$

in content of NDF between samples from the same part of the same species collected at different times of the year. Differences between browse species in content of NDF were related to differences in content of soluble phenolics and insoluble proanthocyanidins. Samples high in NDF were low to moderate in soluble phenolics and high in insoluble proanthocyanidins, such as $R$ hus natalensis and Albizia harveyii. Samples low in NDF were high in soluble phenolics and low in soluble proanthocyanidins, such as Acacia seyal, Acacia nilotica, and Pterolobium stellatum. These relationships led to a high negative correlation between soluble phenolics and NDF and a high positive correlation between soluble proanthocyanidins and NDF (Table 2) as shown in Figure 1. The relationships were similar for ADF (Table 2).

There was a low but significant negative correlation between soluble phenolics and insoluble proanthocyanidins (Table 2). Correlations of soluble phenolics and insoluble proanthocyanidins with other fiber components had the same signs as correlations with NDF and ADF.

Correlations between soluble phenolics, insoluble proanthocyanidins, and other fiber components in Acacia species were similar to those in the overall analysis, except the correlation between (Table 3). NDF-N had a higher correlation with insoluble proanthocyanidins than with NDF. Correlations between NDF-N and hemicellulose and between hemicellulose and insoluble proanthocyanidins were high.

\section{Discussion}

In Acacia species, insoluble proanthocyanidins are associated with higher levels of detergent insoluble nitrogen which may result from formation of tannin-protein complexes. These complexes may be more soluble in acid detergent because insoluble proanthocyanidins form soluble anthocyanidins in acidic solutions (BateSmith 1975). Red solutions of anthocyanidins form when refluxing browse that contain proanthocyanidins in acid detergent. Since hemicellulose is assumed to be the difference between NDF and ADF in the detergent system, this property of insoluble proanthocyanidins would also contribute to higher hemicellulose values.

The behavior of phenolics and tannins in the detergent system is highly variable. Browse with high levels of soluble phenolics ADF and insoluble proanthocyanidins was low and non-significant

(A)

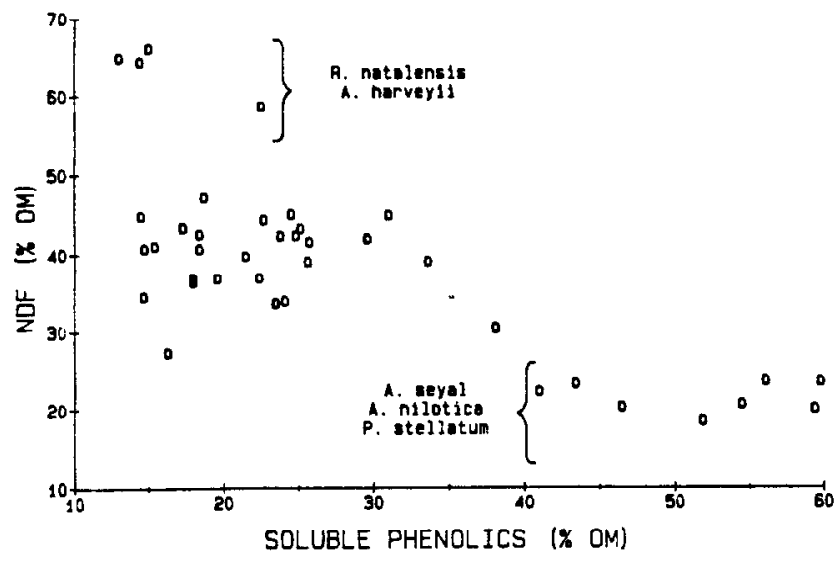

(B)

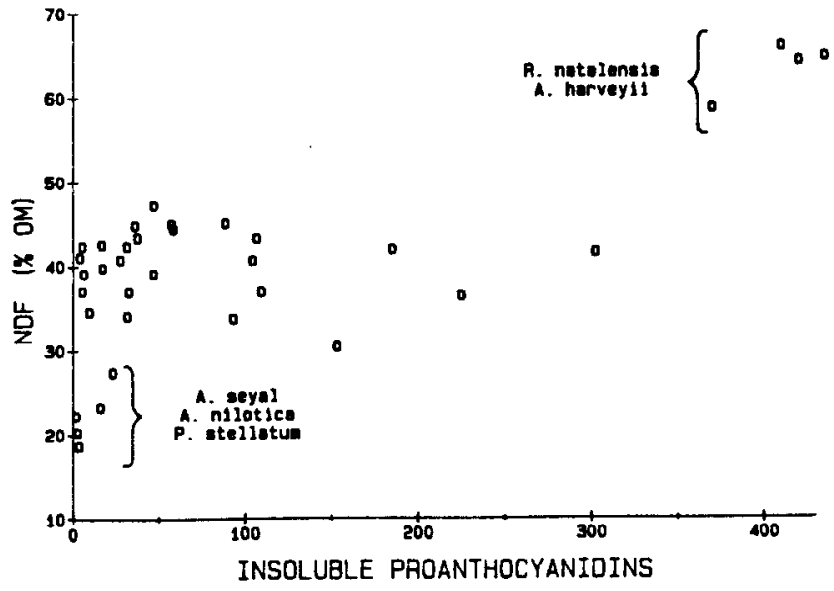

Fig. 1. Relationship between neutral-detergent fiber (NDF) and soluble phenolics $(A)$, and between NDF and insoluble proanthocyanidins $\left(A_{550} / g N D F\right)(B)$ in leaves and apices of East African browse. Rhus natalensis and Albizia harveyii had high levels of insoluble proanthocyanidins and NDF and low levels of soluble phenolics. Acacia seyal, A. nilotica and Pterolobium stellatum had the opposite characteristics.

Table 3. Correlations between neutral-detergent fiber (NDF), acid-detergent fiber (ADF), hemicellulose (HEM), cellulose (CELL), lignin (LIG), neutral-detergent fiber-nitrogen (NDF-N), soluble phenolics and insoluble proanthocyanidins ( $A_{550} / g$ NDF) in leaves and apices from $9 A$ cacia species (17 samples).

\begin{tabular}{|c|c|c|c|c|c|c|c|}
\hline & $\begin{array}{c}\text { Soluble } \\
\text { Pehnolics }\end{array}$ & $\begin{array}{l}\text { Insoluble } \\
\text { Proantho- } \\
\text { cyanidins }\end{array}$ & NDF & ADF & HEM & CELL & LIG \\
\hline$A_{550} / g$ NDF & -0.28 & & & & & & \\
\hline NDF & $-0.89 * * *$ & $0.50^{* *}$ & & & & & \\
\hline ADF & $-0.78^{* * *}$ & 0.15 & $0.86^{* * *}$ & & & & \\
\hline HEM & $-0.72 * * *$ & $0.74^{* * *}$ & $0.76^{* * *}$ & 0.32 & & & \\
\hline CELL & $-0.80^{* * *}$ & 0.07 & $0.80^{* * * *}$ & $0.78 * * *$ & $0.50^{* *}$ & & \\
\hline LIG & $-0.51^{* \pi}$ & 0.20 & $0.69 * * *$ & $0.90^{* * *}$ & 0.13 & $0.44^{*}$ & \\
\hline NDF-N & $-0.73^{* * *}$ & $0.80^{* * *}$ & $0.84^{* * *}$ & $0.52^{* *}$ & $0.90^{* * *}$ & $0.43^{*}$ & $0.47 *$ \\
\hline
\end{tabular}


(greater than $50 \%$ of the organic matter) have high levels of cell solubles. The assumption of high digestibility of cell solubles (Van Soest 1967) in these plants may be misleading and may confound methods for estimating nutritive value based on the summative equation. Large quantities of soluble phenolics may lead to an overestimation of energy value if absorbed and excreted in the urine. Soluble phenolics form indigestible protein and carbohydrate complexes in the digestive tract that increase apparent fiber and lignin excretion in the feces (Osbourn et al. 1971). Prediction of digestibility based on NDF, ADF, lignin or in vitro results need to be adjusted for the content of soluble phenolics.

The NDF from browse with high levels of insoluble proanthocyanidins contains condensed tannins and tannin-protein complexes. The assumption that NDF represents cell wall carbohydrates and lignin in these plants is incorrect. An estimate of the amount of insoluble proanthocyanidin associated with NDF can be obtained by heating NDF in n-butanol- $\mathrm{HCl}$ and measuring absorbance. However, converting absorbance to an equivalent amount of proanthocyanidin is difficult because standards are not available and proanthocyanidins differ widely in their reactivity toward n-butanol-HCl (Swain 1979).

Measurements of soluble phenolics and insoluble proanthocyanidins are essential to the determination of nutritive value because their presence in browse interferes with the detergent system of analysis. This problem needs much more research because the detergent system is widely used and has substantially contributed to understanding nutritional limitations in forages. Relationships among soluble phenolics, insoluble proanthocyanidins and fiber in browse species from the intermountain states (Artemisia tridentata, Populus tremuloides, Prunus virginiana, Purshia tridentata, Salix brachycarpa, Salix planifolia and Vaccinium spp.) were similar to those described for East African browse. These results will be reported in future publication.

\section{Literature Cited}

Bate-Smith, E.C. 1973. Tannins of herbaceous leguminosae. Phytochem. $12: 1809-1812$.
Bate-Smith, E.C. 1975. Phytochemistry of proanthocyanidins. Phytochem. 14:1107-1113.

Ford, C.W. 1978. In vitro digestibility and chemical composition of three tropical pasture legumes, Desmodium intortum cv. Greenleaf, D. tortosum and Macroptilium atropurpreum cv. Siratro. Aust. J. Agr. Res. 29:963-974.

Goering, H.K., and P.J. Van Soest. 1970. Forage fiber analyses (apparatus, reagents, procedures and some applications). Agr. Handbk. No. 379. ARS, USDA, Washington, D.C.

Mould, E.D., and C.T. Robbins. 1981. Evaluation of detergent analysis in estimating nutritional value of browse. J. Wildl. Manage. 45:937-947.

Osbourn, D.F., R.A. Terry, S.B. Cammel, and G.E. Outen. 1971. The effect of leuco-anthocyanins in sainfoin (Onobrychis vicifolia) on the availability of protein to sheep and upon the determination of the acid detergent fibre and lignin fractions. Proc. Nutr. Soc. 30:13A-14A.

Reed, J.D. 1983. The nutritional ecology of game and cattle on a Kenyan ranch. Ph.D. Thesis, Cornell University, Ithaca, New York.

Reed, J.D., R.E. MeDowell, P.J. Van Soest, and P.J. Horvath. 1982. Condensed tannins: a factor limiting the use of cassava forage. J. Sci. Food Agr. 33:213-220.

Reed, J.D., P.J. Horvath, M.S. Allen, and P.J. Van Soest. 1985. Gravimetric determination of soluble phenolics including tannins from leaves by precipitation with trivalent ytterbium. J. Sci. Food Agr. (in press).

Stafford, H.A., and T.Y. Cheng. 1980. The procyanidins of Douglas fir seedlings, callus and cell suspension cultures derived from cotyledons. Phytochemistry 19:131-135.

Swain, T. 1979. Phenolics in the environment. Recent Adv. Phytochem. 12:617-640.

Van Soest, P.J. 1967. Development of a comprehensive system of feed and analysis and its application to forages. J. Animal Sci. 26:119-128.

Van Soest, P.J. 1982. Nutritional ecology of the ruminant. O \& B Books Inc., Corvallis, Ore.

Van Soest, P.J., and J.B. Robertson. 1980. Systems of analysis for evaluating fibrous feeds, p. 49-60. In: Standardization of analytical methodology for feeds: proceedings of a workshop held in Ottawa, Canada, 12-14 March 1979. W.J. Pigden, C.C. Balch, and M. Graham (eds), IDRC, Ottawa, Ont.

Wong, E. 1973. Plant phenolics, p. 265-322. In: Chemistry and biochemistry of herbage. G.W. Butler and R.W. Bailey (eds), Academic Press Inc., London. 